\title{
Avoiding the Pestilence of the State: Some Thoughts on Niche Construction, Heritage, and Sacred Waterworks
}

\section{David Wengrow}

The egalitarian character of traditional irrigation (subak) systems in Bali has been widely documented and discussed by anthropologists, historians, and archaeologists. In a recent study, Stephen Lansing and Karyn Fox considered how the principles of niche construction theory might help to understand the genesis of these systems, as well as certain of their institutional characteristics. Here I discuss how this approach might be extended, to include the relationship between subak systems and the hierarchical organization of the Balinese state, within which they exist. Just as the logistics of subak irrigation work to maintain a symbiosis between rice farmers and the non-human predators (e.g. crop-pests) which surround them, so the ritual elaboration of the agrarian calendar works as a kind of cultural camouflage against the parasitical interests of the state. In theory, these ecological and institutional dimensions of subak may seem to pertain to quite separate spheres of Balinese life. In practice, I suggest, they are intertwined aspects of a single system, which allowed the subak to survive from their origins in the $11^{\text {th }}$ century $A D$, down to their recent inscription on the UNESCO World Heritage List.

\section{Introduction}

In this short discussion, I want to look at some recent uses of Darwinian principles in the study of culture. My focus will be on the development of agrarian ecosystems in a centralised polity, where farmers routinely have to contend both with biological and institutional forms of parasitism on their produce. As a way into this topic, I will consider an application by Stephen Lansing and Karyn Fox of 'niche construction theory' - an increasingly influential stream

UCL Institute of Archaeology,

London WC1H OPY, UK

d.wengrow@ucl.ac.uk of evolutionary thought - which focusses on the subak system of Bali. I assume no prior knowledge either of subak, which I myself know only at second-hand, or the work of Lansing and Fox. What interests me here is their approach to the relationship between ecology, cosmology, and state governance, which I will try to summarise as accurately possible. I will then go on to argue that their approach suffers (as Jane Schneider once said of Immanuel Wallerstein's 'modern world system') from 'too narrow an application of its own theory'.

Subak, as I understand them, are traditional associations of farmers, tasked with management of irrigation systems, which water the terraced paddy fields that descend 
southward from the island's mountainous core, and on which the bulk of its rice crop is grown. In this part of the world irrigation canals, tunnels and weirs form part of a highly complex and unusual ecosystem that has taken form over the past thousand years, and which includes the enclosing forests, villages and hamlets, and a network of water temples located at springs or other key nodes along the watershed. The water temples form an integral part of the subak system. They are the earthly dwellings of spirits, who receive a regular regime of offerings in accordance with a strict calendrical cycle, following the ecological and philosophical precepts of Tri Hita Karana.

Water temples are also the meeting places for committees of farmers, elected to their representative positions on a one-memberone-vote basis. Committees meet regularly to discuss the practical management of the watershed system, planting cycle, and rice harvest, taking on board the different priorities of their constituent farming communities, and seeking equitable outcomes. The subak system has operated in this way for centuries, achieving scholarly fame as a democratic solution to the problems of large-scale agrarian resource management, nested within - yet almost miraculously impervious to - the hierarchical workings of the Balinese monarchy and state, to which it has always paid tithes and revenues, while maintaining intact its distinctly egalitarian modus operandi.

The actual extent of state involvement in the development of the subak system is historically controversial, and in applying the principles of niche construction theory discussed below - Lansing and Fox are concerned to resolve a scholarly debate concerning its origins. The debate that mainly concerns them turns on the issue of whether these highly engineered landscapes, with their intricate webs of arteries and stoppages, grew originally from the 'bottom up' or from the 'top down'. Was their development a gradual and incremental process, arising out of successive local initiatives on the part of small-scale rice cultivators? Alternatively, was the system an imposition by the rajas and their court of a centrally drafted blueprint, executed on a large scale, only later achieving its localized and cooperative character due to modernizing land reforms of the Dutch colonial authorities, subsequently reinforced by the government of Indonesia (Schulte Nordholt 1996).

Most of Lansing and Fox's (2011) study is devoted to resolving this problem through a historical application of population genetics, which comes down firmly on the side of the 'bottom up' explanation. In reaching this conclusion, however, their rich and instructive paper raises wider questions about the relationship between agrarian ecology, innovation, and political evolution. What concerns me in particular is their suggestion that a bottom-up view of the evolution of the subak system 'may be consistent with the principles of niche construction theory', while the top-down view, they suggest, "is probably not'. In a similar vein they propose that while certain aspects of the subak's evolution - such as the circulation of ecological knowledge throughout the system - may be amenable to analysis in Darwinian terms, other aspects - notably the agrarian calendar and its implementation through water temple rituals - are probably not. The question I want to pose, again without assuming any deep knowledge of their subject matter, is whether these kinds of analytical distinctions are, in fact, logically consistent or necessary. First, however, I should briefly outline the principles of evolutionary biology that Lansing and Fox are seeking to apply.

\section{Some limits to a neo-Darwinian analysis of culture?}

Niche construction theory is a strand of Darwinian theory, which seeks to characterize the dynamic relationship between organisms and their environments as an evolutionary process; how each modifies the other in a reciprocal way. Its central claim is that such reciprocal shaping of environments and organisms has consequences for genetic inheritance that are non-trivial. This constitutes a challenge to the primacy of 
'adaptation' as a way of understanding biological evolution (the problem with adaptation being that it posits an ontological separation of 'environment' and 'organism' that never actually occurs in reality). Rather than simply acting as passive carriers for their genes, living organisms - through activities such as building nests, burrowing into soils, or metabolizing one another's waste products - are constantly extending their phenotypes beyond the biological body. In doing so, they are not merely modifying their habitats, but also passing such modifications on to successive generations, in ways that alter the context of natural selection.

Niche construction thus posits a more active role for organisms in the evolutionary process than has conventionally been allowed. 'Active' here has a strictly limited meaning, because the actors themselves remain essentially blind to the larger processes in which they are engaged. Small activities on the part of organisms thus have cumulatively larger effects, both on their own niches and those of other species; and these effects are often highly complex, with ramifications spiralling across a 'huge range of temporal and spatial scales', far beyond the purview of any particular actor or group of actors. An example of this kind of spiralling complexity is Naiman, Johnston and Kelley's (1988) study of how North American beavers - if left to their own devices - will quite unconsciously impose a hierarchical pattern of considerable extent on the landscapes they inhabit.

Beavers do this by building dams, which inhibit stream discharge, allowing them to construct stable islands for their raised family lodges, where they can better evade the attention of predators. In doing so they also contribute to the formation of organically rich wetlands. These in turn change the composition of invertebrate communities, encouraging the multiplication of microscopic collectors and predators - such as midges and dragonflies - that attract frogs and birds; and the harvesting of wood for building activities alters the nature of terrestrial ecosystems near beaver populations, with knock-on effects for some hundreds of other species. In what ways, then, might it be instructive to compare the dam-building activities of beavers to the irrigation networks of the Balinese subak system; and in what ways not?

This, it seems to me, is the kind of question that is ultimately posed, not only by Lansing and Fox's (2011) paper, but more generally in the effort to apply Darwinian principles to human cultural endeavors. In the Balinese case, their answer focusses on the unconscious but essential role of non-human crop predators (i.e. pests such as grasshoppers, locusts, and rats) in propping up the institutional foundations of the subak system. Like all rain-fed irrigation systems, those in question here accord upstream farmers certain advantages over their downstream neighbours in terms of access to and control over the distribution of water. Lansing and Fox make the intriguing case that, in a world without crop pests, there would be no incentive for the former to surrender some portion of their water supply to the latter, and the egalitarian ethos of the subak system would therefore face routine challenges from the inherent inequities of irrigated rice farming.

Crucially, however, pests - unlike water can and do travel upstream as well as downstream. The most effective way of controlling their movement and reproduction is for farmers to synchronize their planting schedules at an inter-community level. This allows them to create large areas of fallow that are hard for pests to cross, and to periodically flood out harvested fields to deprive them of their favoured habitats (all the while exchanging information about the overall water supply to avoid fatal shortages in arable fields). Both through historical evidence and mathematical modelling, Lansing and Fox are able to show that cooperating on this scale will routinely generate greater rice yields for all concerned. In this way, they identify an evolutionary feedback between "the selection of irrigation schedules and the occurrence of water shortages or pest infestations', which not only promotes the egalitarian ethos of the 
subak system, but also demonstrates its superiority over other forms of crop management.

The latter point is neatly demonstrated by a short and abortive intervention in the subak system on the part of the Asian Development Bank, which took place in the 1970s. Agricultural innovation was then encouraged by new and fast-growing rice strains, which allowed a more compressed and intensive cropping schedule. The effect was a breakdown in the collective timing of fallow and flooding, accompanied by an initial boom in rice yields, followed by catastrophic bust, as pestilence set in across the landscape to a degree previously unknown. The traditional subak system was quickly reinstalled, and its historical survival can therefore be legitimately attributed, at least in part, to the predatory activities of crop-pests.

It is this mutual interdependence of human and non-human populations in reproducing a balanced ecology that allows Lansing and Fox to accurately model certain aspects of the subak system, using the Darwinian principles and mathematical procedures of niche construction theory. As they point out, the models work insofar as 'the role of conscious intention is limited to the readiness of adaptive agents to seek better harvests by imitating their neighbors'. But as they also acknowledge, this type of modelling provides only an impoverished account of what actually constitutes the subak system and makes it function. In particular, it offers no obvious way of accounting for the role of water temples and the sophisticated calendrical rituals that underpin both the organization of agricultural labour, and the moral obligation to work on another's behalf for the greater good.

This is no small point, and not just because the rice farmers consider themselves and their labour to be part of a grander cosmological scheme. The Balinese gods of the countryside - like those of ancient Greece, India, and Rome - constitute far more than an ideological gloss on the agrarian economy: they are explicitly linked to particular functions within the agrarian cycle, and their festivals provide a kind of 'ritual clock' that also organizes the practical activities of weeding, planting, harvesting, and so on (Lansing 1991). Moreover, epigraphic evidence allows us to trace the history of water temples back to the very beginnings of the subak system in the $11^{\text {th }}$ century AD, indicating links between the two phenomena of both a functional and developmental nature.

Why exactly, then, are Lansing and Fox reluctant to include the agrarian calendar and its specialized water cults in their Darwinian modelling? In their own words: the 'historical development of this concept of nested temporal cycles and its successive application to many aspects of the phenomenal world is not well captured by a Darwinian perspective'. Extended applications of the subak calendrical system, to which they refer, include all sorts of things that have no immediate or obvious connection to agriculture, such as the arrangement of systems of cosmology, literature, musical notation, and even personal names and identities, which change stepwise with the agrarian metacycle, as individuals take on new roles as parents, grandparents, and great-grandparents. Little of this, in Lansing and Fox's (2011) view, is amenable to a Darwinian perspective, or to niche construction-type modelling:

Instead, it appears to reflect what Hegel described as the desire of Reason to make the world congruent to itself. . . . The consistent application of this abstract notion to so many aspects of the Balinese world contributed to a mental and physical landscape of pleasing harmonies and perceptible coherence... Mere tinkering can explain how Balinese farmers engage with their calendars, names, musical compositions or irrigation schedules, but it cannot explain how their world comes to be experienced as a coherent and rational whole.

Or to put it another way, the utility of Darwinian analysis decreases as we shift our gaze from the 'outside' to the 'inside' of Balinese temple 
culture - from its observable effects on the physical world to people's perception of what gives meaning to those acts. Lansing and Fox effectively confront the proponents of niche construction with a theoretical ultimatum. Either they will have to extend their approach beyond Darwinian principles, to embrace the philosophy of Hegel and perhaps the teachings of the Frankfurt School; or they will have to accept some stringent limits on its ability to explain the development of culture.

\section{Cultural camouflage and the pestilence of the state}

Is this really so? What I want to suggest, in developing my own position, is that the quality of Lansing and Fox's analysis allows for another-more parsimonious-interpretation of their own findings, which points towards an alternative understanding of the relationship between human ecology and political process. What they have failed to build into their model (or at least this will be my argument) is that the subak system at any given point in its development is involved in two quite different sorts of predator-prey relationship. First, there is the non-human predation of irrigated rice fields by grasshoppers, locusts, rats, and so on. But then there have also been the extractive interests of the Balinese king and his nobles, or, more recently, of the government and investment companies of Denpasar, with its burgeoning tourist industry.

Brigitta Hauser-Schäublin (2005), for instance, has shown how at various points in the long history of the subak system the state has attempted to infiltrate its inner workings for the purpose of increasing revenue, for instance by sponsoring the erection of ancestral shrines in water temples, or by manipulating the electoral process of the subak councils. Documentary sources, such as the Batur palm leaf manuscripts of the $18^{\text {th }}$ and $19^{\text {th }}$ centuries, show how the temple and its authorities were constantly trying 'to keep as much autonomy as possible while co-operating with the supreme king in different ways'. The extent of state interference has waxed and waned through the centuries, but clearly, it has been just as omnipresent a threat to the viability of the subak as the perennial invertebrate attackers of their crops.

Lansing and Fox describe and model some of the methods by which the subak manage to repel predation of the non-human kind. One might equally ask how they have managed with similar success, and over a period of many centuries, to avoid the worst implications of the second kind of predation, the human kind. The materials for an answer, I suggest, are in fact largely provided by Lansing and Fox and they can be expressed if not formally modelled - in terms of predator-prey (and perhaps also parasite-host) relations, using the familiar conceptual tools of evolutionary biology. What I am arguing, in brief, is that those aspects of the subak system that they find hardest to explain in Darwinian terms actually have a sound adaptive function. They work effectively as a type of 'cultural camouflage' that shields the system as a whole, and grants it a degree of immunity from the parasitical and predatory interests of outside (human) agencies (cf. Napier 2003).

In Bali, as Lansing and Fox note, statesponsorship of foreign deities, mainly of Indian (Buddhist or Hindu) origin, extends back to first millennium AD. But as they also note, these imported deities 'play virtually no part in temple rituals', evoking a familiar contrast between the alien 'gods of the city' and the local 'gods of the countryside'. While the former have rich personalities and are the subjects of elaborate mythological narratives (again much as in ancient Greece and Rome), the latter are essentially instantiations of particular moments in the agrarian calendar, their supernatural powers fixed to the allocated functions of weeding, harrowing, harvesting, and so on. So the ritual life of the water temples forms a kind of counterreligion to the religion of the state; just as its political life forms a kind of counter-politics to the rules of caste, nobility, titles, private property, landed wealth and other inherited privileges that have historically characterized the political life of the Balinese state. 
By extending the state-repelling principles of the agrarian ritual calendar to encompass other key facets of cultural life and personal identity, the subak have achieved a kind of insulating or 'cocooning' effect, wrapping their irrigation system in protective cultural materials, such that to disturb it means far more than a change in landscape management. It means the disruption of a total form of social life, and a dazzlingly complex and elegant one at that. By shaping the surrounding world to its own pattern of growth and reproduction, the subak system effectively extends its 'niche' beyond observable nature and toward the heavens; a kind of cultural apotheosis most recently enshrined by its 2012 inscription onto the UNESCO World Heritage List. The discovery of this newfound niche as a protected heritage landscape of international standing represents the successful extension of processes by which the subak have survived over the centuries, raising themselves, repeatedly, above the pestilence of the state.

To be clear, none of what I have said implies reducing the organizational habits of Balinese farmers to something like the actions of 'cathedral termites'. To the contrary, it simply acknowledges that the protective powers they claim to harness through water festivals are a great deal more than historical baggage or ideological 'mumbo-jumbo'; they are effective and malleable defences against state predation and state parasitism in the modern world. If so, then this might indicate how the interface between ecology and political evolution can be usefully studied - not so much by shifting philosophical ground from Darwin to Hegel - but by examining the cultural permutations of such standard biological mechanisms as prey-predator or host-parasite relations in all their most creative and Machiavellian varieties, and relating these back to ecological models.

\section{Competing Interests}

The author has no competing interests to declare.

\section{References}

Hauser-Schäublin, B 2005 Temple and king: resource management, rituals, and redistribution in early Bali. Journal of the Royal Anthropological Institute, 11: 747-771. DOI: https://doi.org/10.1111/ j.1467-9655.2005.00260.x

Lansing, J S 1991 Priest and programmers: technologies of power in the engineered landscapes of Bali, Princeton, Princeton University Press.

Lansing, J S and Fox, K M 2011 Niche construction on Bali: the gods of the countryside. Philosophical Transactions of the Royal Society B: Biological Sciences, 366: 927. DOI: https://doi.org/10.1098/ rstb.2010.0308

Naiman, R J, Johnston, C A and Kelley, J C 1988 Alteration of North American streams by beaver: the structure and dynamics of streams are changing as beaver recolonize their historic habitat. BioScience, 38: 753-762. DOI: https://doi. org/10.2307/1310784

Napier, D 2003 The Age of Immunology. Chicago and London University of Chicago Press. DOI: https://doi.org/10.7208/ chicago/9780226568140.001.0001

Schulte Nordholt, H 1996 The spell of power: a history of Balinese politics, 1650-1940. Leiden: KITLV Press. 
How to cite this article: Wengrow, D 2017 Avoiding the Pestilence of the State: Some Thoughts on Niche Construction, Heritage, and Sacred Waterworks. Archaeology International, No. 20: pp. 137-143, DOI: https://doi.org/10.5334/ai-364

Published: 14 December 2017

Copyright: (c) 2017 The Author(s). This is an open-access article distributed under the terms of the Creative Commons Attribution 4.0 International License (CC-BY 4.0), which permits unrestricted use, distribution, and reproduction in any medium, provided the original author and source are credited. See http://creativecommons.org/licenses/by/4.0/.

] A A Archaeology International is a peer-reviewed open access journal published by Ubiquity Press. 